\title{
Place of Causativity in the Language System of the Azerbaijani and English languages
}

\author{
Chinara Vagif Abdullayeva ${ }^{1}$ \\ ${ }^{1}$ The Academy of Public Administration under the President of the Republic of Azerbaijan, Baku, Azerbaijan \\ Correspondence: Chinara Vagif Abdullayeva, The Academy of Public Administration under the President of the \\ Republic of Azerbaijan, Baku, Azerbaijan. E-mail: c.v.abdullayeva@mail.ru
}

Received: November 29, 2019

Accepted: February 8, 2020 Online Published: March 22, 2020

doi:10.5539/ijel.v10n3p211

URL: https://doi.org/10.5539/ijel.v10n3p211

\begin{abstract}
"The English-Azerbaijani Dictionary" gives the following definitions for the words "causative" and "causation" in Azerbaijani: 1) Səbəbiyyət (act of causing); 2) Səbəblik (causation); 3) Hadisələr arasında səbəb əlaqəsi (causative relations among the events) [The English-Azerbaijani Dictionary, 2003]. Thus, by causativity or causation the linguistics mean the relations of cause and consequence. The category of cause and consequence has been attracting the attention of philosophers, textual critics and linguists since the antiquity. Bunge, who studied this category particularly, notes that the category of causation functions as a special type of mutual actions or mutual interdependence. The relation of cause and consequence as a philosophical category complete each other. As the human language reflects the realities, the relation of cause plays an important role as the category of time in the syntax of the sentence (Bunge, 1962).
\end{abstract}

Keywords: causative verb, cause, speaker, hidden category, transitive verb

\section{Introduction}

The relation of time and cause acquires certain importance from the point of view of expressing a certain speech situation. Time and cause relations differ from other syntactic relations by their broad sense of expressing opportunities. Undoubtedly, we are interested here not in cause and consequence relations, but in cause and consequence relations within a sentence taking place under the influence of the subject. In other words, we are interested in the phenomenon of causation, which takes place within one sentence. In causative constructions the subject of the sentence functions not as the doer of the intended action, but as its initiator. Thus, as a result of one cause a second cause becomes evident. Causativity is a semantic unit formed on the ground of subject-object relations reflecting the causative sense in itself. Central conceptions in causativity are causitive situation. Its obligatory participants are: a) generator (or source) of causation, which causes the object; b) object of causativity or causate. Two main participants of causativity (subject and object) determine the process of causation.

\section{Scope of the Study}

Sometimes in linguistic literature there is a misunderstanding in the usage of the terms of causativity and causativity. Just because of it there is a need in disclosing the essence of these terms. In our study we proceed from the views of Baklagova. She notes that causality in its broad sense expresses much broader meanings: initial condition, determination in advance, consequence, stimuli, purpose, etc. Causality expresses dependence of cause by syntactic means (conjunctions, means of combining and their equivalents). The expression of causativity finds its expression directly in different types of subordinate clauses. Unlike causality causativity is a lexico-grammatical category, which reflects the cause and consequence relations between the subject and object (Baklagova). One may make such an inference from this that irrespective of the type of causativity verbs form its basis, its centre, but complex sentences and different prepositional combinations form the basis of causativity. Proceeding from this difference we think that it is expedient to use the terms causality, causative and causation in our studies.

Both causality and causativity play an important role in the reflection of reality in the language. These both categories are universal in nature. Depending on the grammatical structure of any language these categories find their expression by different means. The speaker and listener and their knowledge about the objective reality form the basis of communication, it also defines the means and devices used in communication. The means and 
the cases in which they are used, the information (knowledge) of the speaker and the listener on the objective reality form the basis of the communication. Thus, the functional features are moved to the forefront. It is not accidental that at the beginning of the $60 \mathrm{~s}-70 \mathrm{~s}$ of the past century there emerged new directions in linguistics, which studied the relations of the speaker and listener in the formation of communication: a) pragmatic linguistics; b) cognitive linguistics.

Pragmatics is the branch of linguistics concerned with meaning in the context, or the sense of sentences in terms of the speaker's intentions in using them.

Most of all, pragmatics is a field of linguistics, which studies different aspects of the relations of the speaker and listener in the process of speech.

At present another branch in linguistics is the cognitive linguistics. According to Veyselli, the main purpose of this linguistics is to determine the status of the language in the system of cognition. In general, cognition is the reception, deposit, reutilization and transmission of information in the brain (Veyselli, 2015). In the frames of the cognitive paradigm the language is the main expresser of the cognitive activity of the man. Language and thinking are closely connected with each other (Veyselli, 2015). The main idea of cognitive studies reflects the cognitive structures, which reflect the environment mentally. The smallest units or particles of the cognitive structure are the concepts. Concept deposits the knowledge of the man about the world in the memory (Veyselli, 2015). According to Abdullayev, concepts emerge in the process of cognition of the reality by the man and reflect the information connected with the environment (Abdullayev, 2011).

Another important notion of the cognitive linguistics is the conceptfers, that is, the sphere of knowledge, the units of which consist of concepts. It includes pictures, frames, schemes, notions and scenarios (Abdullayev, 2011).

Language takes part in the process of the birth of concepts in the consciousness directly. The relation of consciousness to the environment is realized by means of the language. In this process language realizes the exchange of information. Thus, cognitive linguistics is a field of science, which plays an important role in the precision of the issues of consciousness and thinking, and which seems interesting (Veyselli, 2015).

Our aim here is not to tell something new about the pragmatic and cognitive linguistics. We simply try to convey the views of different linguists existing in theoretical literature. We think that the universal language category, that is, causativity as a logical-philosophical category reflects the pragmatic-cognitive peculiarities.

\section{Causative and Causativity Relations}

Causative and causativity relations form a binary depending on their nature. Each of them has a definite purpose. Causality is based on a certain event, fact or condition. For instance: Hava soyuq olduğuna görə biz evə qayltdıq (The weather being cold, we returned home). But the causative relation expresses the information for changing the state of the thing, which will take place in something or somewhere obligatorily. For instance: $O$, məktubu sabah göndortdiracok (He will have the letter sent tomorrow). Thus, causality shows the action, which takes place as a conditional dependence; causativity shows the action which takes place as a result of instigation. Undoubtedly, the use of causativity or causality is not spontaneous. The use of each of them depends on the concrete speech situation and on the background knowledge of the speaker or listener.

Causality and causativity attract the attention of philosophers and text critics more than that of the linguists. It is noted that nothing may exist without its cause and the existence of anything may be terminated without a reason. Anything, which happens, turns into a reality as a result of some consequence. Anything having a beginning must have a cause (Bunge, 1962).

We can make such an inference from the said that the principles of causativity play an important role in the formation of obligatory relations existing among the things. The formation of the relations of cause and consequence in the language has always attracted and are still attracting the attention of the linguists up to the present day.

From this point of view, it will be expedient to appeal to the classical literature. Speaking about the relation of causativity the French linguist Charles Bally noted that the said relation is connected with the transitive verbs. According to him, the syntactic expression of causativity takes place on the grounds of agreement and government. Depending on certain causes the following results are obtained:
a) A turn into $B$ as a result of a cause;
b) as a result of a cause $\mathrm{A}$ is in $\mathrm{B}$, or on the contrary, B is in A;
c) the wind compels the leaves fall (külək yarpaqları düşməyə macbur edir); 
d) the snow whitens the mountain (qar dăğ ăgardir);

e) Pavel moves the chair towards the table (Pavel stulu stola toraf italayir).

Charles Bally makes such a conclusion that such constructions express casual relations in use; it gives us a reason to say that there are hidden devices in the language. Such relations are numerous and heterogeneous. On the grounds of cause and consequence there is an interaction of two compound notions (Bally, 1955). Bally classifies the frequently used syntactical models into groups like the followings:

1) The phenomenon of causativity takes place as a result of the use of analytical forms of two verbs standing next to each other. The following types of sentences are presented for this purpose. For instance: Pavel compels Petrov to work. Pavel orders the tailor to sew him a new suit (Pavel Petrovu işlaməya macbur edir. Pavel darziya paltar tikmayi sifariş edir).

It is necessary to note that the verb to make (macbur etmək) plays an important role in the expression of causativity as a universal means. We shall see below that this model functions in English as one of the main means for the expression of causativity in English. For instance: The man made them leave the garden.-Kişi onları bağı tark etmaya macbur etdi. The man ordered them to leave the garden.-Kişi onları bağı tərk etmaya amr etdi.

2) Bally notes the cases when causativity takes place as a result of the causative relations, that is, as a result of causativity one quality or form changes into another. For instance: Pavel makes his parents happy (Pavel valideynlarini xosbaxt edir). There are cases when causativity becomes obvious from the logic. For example, let us take the verb to give (vermək). We can transform the sentence Pavel kitabi Petrova verir (Pavel gives the book to Petrov) very easily: Pavel elo edir ki, kitab Petrovda olsun (Pavel does so that the book remains in Petrov). As it was noted above, in the sentence models of this type a hidden cause takes place.

3) Causative verbs play an important role in the expression of causativity. These verbs fulfill two functions simultaneously: a) they create a relation between the subject and object; b) they are able to change their quality and form by having an impact on them. Bally includes the following verbs into the group of these verbs: 1) sevindirmək - şən olmăga macbur etmək (to gladden - to compel to be glad); 2) ăgartmaq - ăg olmağa macbur etmak (to whiten - to compel to be white); 3) ranglamak - nayinsa rangini dayişmək (to paint, to colour -to change the colour of something) (Bally, 1955).

The verbs dağıtmaq (to destroy), öldürmək (to kill), məhv etmək (to annihilate), bişirmək (to cook) and others are also included into the group of causative verbs.

We should like to note that Bally built his theory on the basis of facts of the French language, nevertheless, the majority of the linguists proceeded from his theory on causativity, though they were dealing with facts of quite different languages. Simply they appeal to the materials of different languages having different grammatical structures.

It will be to the point to mention the views of Chafe concerning the causativity. Speaking about causativity he approaches it whether the verb expresses a state, or an action. Comparing the sentences: The door is open (Qapl açıqdir), The road is wide (Yol genişdir), The door opened (Qapı açıldl), The road has been widened (Yol genişlandirilib), he makes such an inference that in the first case the sentences express the state of something, in the second case - an action. In the second case the word forming suffixes -ed, -en transform one lexical unit into new lexical units with new meanings Thus, the relations of causativity take place in them (Chafe, 1975). Then demonstrating the sentences like Linda broke the dish, W.Chafe makes such an inference that the sentences of this type emerge as a result of the process of causativity (Chafe, 1975). The explanation given by him assures us that he gives a certain place to the word forming means in the expression of causativity. For instance: The explosion deafened Roger (Partlaylş Rocanı kar etdi) (Chafe, 1975).

The views of Katsnelson concerning the causativity attract the attention, too. When one gets closely acquainted with his views about the hidden category and causativity, it becomes clearly evident that he has developed and improved the views of Bally concerning these categories. He notes that the hidden categories fulfill many important functions in the language system. Among them the syntactic valency and hidden changes in lexical meanings occupy an important place. He makes such an inference that it is still topical to study the hidden categories in the language system along with the concrete grammatical forms (Kachnelson, 1972). It becomes evident that the studies conducted on the materials of different languages prove that the causative verbs do not have distinguishing morphological or syntactic features. Causativity finds its expression depending on the lexical meaning and syntactic function of the word in the sentence.

The views of Tenier on causativity differ from those of other linguists considerably. He relates the causativity of 
verbs to the valency of verbs. In other words, he thinks that causativity depends on the actants of the verb, in other words, on the number of the members of the sentence, which the verb combines. Proceeding from this point of view, he classifies the verbs according to the number the actants (Tenier, 1972).

1) Mono-actant verbs: düşmək - to fall, ölmək - to die, getmək - to go, etc. Top düşdü - The ball fell down, Uşaq getdi - The child went away, Düşman öldü - The enemy died. As it is seen from the examples, L.Tenier does not use the term "intransitive verb", but undoubtedly, he means the intransitive verbs.

2) Two-actant verbs: ylxmaq - to kick down, öldürmək - to kill, görmək - to see. By two-oactant verbs the transitive verbs are meant, such verbs are used with objects:

$O$, düşməni öldürdü - He killed the enemy.

$O$, dostunu gördü - He saw his friend.

3) Three actant verbs: göndərmək - to send, göstərmək - to show, demək - to say, vermək - to give, etc. The transitive verbs of this kind admit two objects (direct and indirect). For example:

Tom sent Mary a book. - Tom Meriya bir kitab göndardi.

Tom showed Mary a picture. - Tom Meriya bir şakil göstardi.

Tenier comes to such a conclusion that increase of the number of the initial actant leads to the birth of a causative verb. For example: ylxllmaq -fall down (non-causative), ylxmaq - to knock down (causative); ölmək - to die (non-causative); öldürmək - to kill (causative) [Tenier, 1988].

In three-actant verbs the causativity is formed like in the following model. For example: Polis oğrunu yaşadiğ ünvani söylamaya macbur etdi - The police made the thief tell his address. It is necessary to note that the demonstrated model is existing in several languages as a universal model.

The causativity of three actant verbs may take place in the model given below. For example: Şarl kitabı Alfredo verir - Charles is giving the book to Alfred.

The causativity of four actant verbs may take place in the model below. For example: Daniyel Şarl macbur edir ki, kitabr Alfreda versin - Daniel compels Charles to give the book to Alfred.

It must be taken into consideration that the majority of examples demonstrated by L.Tesnier have been introduced in conformity with the grammatical structure of the French language. Unlike other scholars L.Teniere says that the causativity is also connected with the passive voice of the verb [Tenier, 1988]. It is natural, because, as a rule, the passive voice of the verb is built with the transitive verbs. The majority of the verbs are known as transitive ones. For instance, in the modern English language in sentences having subject-infinitive composition this case strikes the attention more. For example, Tom was made to leave the room. - Tomu otağ tark etmaya macbur etdilar.

At the same time L.Tesnier says that causativity is connected with the flexive voice of the verb. For instance, $O$, özünü öldürdü (he killed himself) (Tenier, 1988).

Taken wholly, Tenier's arguments are based on the materials of the French language and he discloses his views on causativity and on its essence, which are very valuable. Another attractive view of Tesnier is that he mentions the idea of translating the causative verbs from one language into another. He devotes a special chapter to the issue under the title "Metataxis and Causative". By metataxis he means the structural changes taking place in the translation from one language into another (Tenier, 1988). As it is known, not only different languages, but even within one and the same language, the means of expression of causativity is variegated and different. Causativity is expressed analytically in some languages, synthetically in others. The visual example of it can be seen in the means of expression of causativity in the Azerbaijani and English languages. In Azerbaijani causativity is expressed synthetically, in English — analytically. For instance: Məktubu ona göndərtdim. - I made him send the letter.

Speaking about causativity, it will be to the point to mention the views of Arutyunova. She moves to the forefront the interrelation of the members of the sentence in the disclosure of the essence of causativity. She notes that as a result of causativity the person creates the real causative situation and thus, causativity is realized as a result of a syntactic combination (Arutyunova, 1976). Her views on the hidden causativity and on its essence, which are based on the materials of the Russian language, are very appreciating. Speaking about the hidden causativity, she divides it into two groups: a) hidden causativity with two agents: b) hidden causativity with one agent. Causativity with two agents merges two events: Мать накормила ребенка - Ana uşăg yedizdirdi (Mother made the child have the meal). On one hand, yedizdirmak (to have the meal) means to feed, on one hand, 
qidanı qabul etmak means to take the food, on the other hand. In such cases causativity with two agents reflects two situations, which executes two actions: a) giving the meal; b) having the meal. In causativities with one agent we have in mind the action which is taking place and its consequence. For instance: Я ломал прут - Мәп çubuğu sindırdım (I broke the stick) (Arutyunova, 1976).

At the same time Arutyunova notes that a single (one) agent may take place after a number of transitive verbs: Он сиил себе новый костюм - $O$, ӧzӥn у yeni kostyum tikdi - He sewed a suit for himself. At the end she comes to such a conclusion that the lexical meaning of the verb plays an important role in the expression of the hidden causativity, a syntactical relevance does not take place there (Arutyunova, 1976).

When speaking about the causativity it would be useful to review the studies of Zolotova. Dealing with the materials of the Russian language she focuses attention on the causativity on the sentence level. She is just in noting that in order to penetrate into the depth of the essence of causativity it is necessary to pass from lexical level to the syntactical level. Speaking about the syntactical expression of causativity she mentions the infinitive combinations (Zolotova, 1973). The action to be performed in that composition is executed neither by the subject, nor by the predicate, but by the object. In other words, the subject compels the object to perform an action: $\mathrm{OH}$ заставил его вернуться домой - Не made him return home - $O$, опи eva qayttmağa macbur etdi.

Taken wholly, the studies of Zolotova acquire certain importance for the investigation of this problem in other languages.

Speaking about the history of the means of expression of causativity, it is necessary to mention the monograph “Типология каузативных конструкций. Морфологический каузатив” (Typology of causative constructions. Morphological causative). That monograph touches upon the issues, which may acquire importance for other languages. They are the means of expression of causativities. But one common feature finds its reflection in the majority of studies, that is, causative situation must consist at least of two micro situations: a) instigator; b) the one who is subjected to instigation. Depending on the grammatical structure of the language any causative situation emerges in the form appropriate for it. It should be noted that in the majority of studies devoted to causativity the above-mentioned monograph is touched upon.

One may ask: "Are there studies devoted to causativity in the linguistics of Azerbaijan?" We imagine that the answer to the question will be like this: In the Azerbaijani language causativity finds its expression morphologically in the causative voice of the verb; therefore, it has not so much attracted the attention of the investigators. Nevertheless, we should like to mention one of such studies conducted recently that is "The expression of the notion of compulsion in language" by Yusifova (Yusifova, 2015). It becomes evident from the provisions and goals of the study that the investigator imagines the notion of compulsion much broader. We think that though causativity expresses some compulsion, yet it is regarded as a part of the notion of compulsion. We think that though causativity expresses compulsion in some degree, yet it differs substantially from the notion of compulsion due to its essence and means of expression so that not all the compulsions express causativity. It is fairly noted in the recent researches that in imperative there is performative but in causative there is information about the action (Khanbutayeva, 2018). Nevertheless the mentioned research work acquires a certain importance for the linguistics of Azerbaijan. We shall try to disclose our attitude to the problems having something in common with our study.

Basing on the results of the studies on the causative category we can make such an inference that causativity as one of the universal language categories catches the attention. The analysis of the language materials shows that causativity finds its expression not only in different languages, but even within one and the same language. Though it is universal in nature, it is important to proceed from the grammatical structure of each language separately. It is not expedient to apply the grammatical phenomenon of one language to another one spontaneously. We observe it in our research work, which is connected with the Azerbaijani and English languages. Though these two languages belong to two different language families, they display the mentioned features from the point of view of causativity.

In Azerbaijani causativity is expressed synthetically by means of the causative voice of the verb, but in English in many cases it is expressed analytically, if it is possible to say. For example: Mən məktubu göndərtdim. - I had the letter sent.

As it becomes obvious from the examples, the differences between the two languages tell of themselves not only from the point of view of expression, but also from the point of view of the doer of the action. In Azerbaijani the sender of the letter is unknown, but in English the doer of the action is known. At the same time the basic difference between these two sentences is the word order inherent to them. Nevertheless, we observe identical things existing in both languages. Depending on the means of expressing and the number of means expressing 
causativity, we may speak of two forms of causativity: a) simple causativity, b) complicated causativity.

Simple causativity emerges as a result of a cause. In this case pure causative verbs are used: to order - əmr etmək; to cause - sabab olmaq, to force - macbur/vadar etmak etc. The simple causativity is built on the following model (Reidel, 1971). The man forced the boy to follow him. - Kişi oğlanı onun ardinca getmaya macbur etdi.

Thus, in simple causativity the subject compels the object to perform an action, that is, the cause leads to the consequence.

In complicated causativity the subject acts against the object and also compels it to change its position. As a result of it, the object acquires a new form or condition. For instance: The boy broke the window. - Oğlan pancarani sindirdl.

It becomes known from the examples that causativity takes place within a concrete time and space. Because of it three processes of causativity are shown within the space. From this point of view the statement made by Toshovich plays an important role in the disclosure of the essence of causativity. He notes that there are three processes in the space (Toshovich, 2000):

a) action - any active process in the space;

b) replacement - going to some other place. It may take place by means of a transport;

c) change of situation - in it various things may take place: vertical, bending, standing, lying, sitting, hanging, circular, downwards, upwards, backwards, to the right, to the left, etc.

Based on these three noted principles, Toshovich divides the spatial causativity to three semi-groups. We think that this classification plays an important role in the disclosure of the essence of the space. Just because of it we think it expedient to take this classification as a basis in our investigation.

Action causativity is such a kind of causativity that someone compels anything, or a part of it, or other thing or a part of it to move from one space to some other space. For example:

1) The man made the children leave the garden. - Kişi uşaqları bağı tərk etmayə macbur etdi.

2) The boy sent his parents a letter. - Oğlan valideynlarina məktub göndərdi.

In both sentences under the influence of the subject the object is compelled to change its space. In the first sentence the children are obliged to change their place at least for several metres, they are compelled to move from one space to another one. It is natural that in the second sentence in consistence with the logic the space is changed for the delivery of the letter from one space to another one. In replacement causativity someone influences the replacement of a thing, or a part of it, or another thing, as well as a part of it in a certain space. For example:

1) The pupil put the books into the bag. - Şagird kitabları çantanın içina qoydu.

2) He moved the table to the corner. - O, stolu künca qoydu.

When we pay attention to the examples it is clearly felt that in both sentences the thing, which is subjected to an influence, changes its place. The situation in the first sentence can be imagined like this: the pupil puts the books into the bag after doing his lessons. In the second sentence replacement takes place on the same design:

a) Any article or thing, or a part of it influences the change of its place. For instance: 1) He slept. - O, yatdl. He lay. - $O$, uzandl. 2) He raised his hand. - $O$, alini qaldırdl.

In the first two sentences we have self (auto) causation. Here a hidden grammatical category takes place: $O$, oyaq idi. Sonra yatdl. O, işlyyirdi. Sonra uzandl. He was awake. Then he slept. It means that one condition or state was replaced by another one. In the second sentence the subject changes the state of his hand. By raising his hand he conveys information that he is ready to answer the lesson or wants to say that he has a question to ask.

b) A thing changes the state of a thing or a part of it by exerting influence on it or on a part of it. For example: 1) The wind broke the tree. - Külak ăgacı sindirdı. 2) The wind broke the branches of the tree. - Külak ağacin budaqlarinı sindirdi.

In the first case the object is wholly subjected to an influence. In the second case a part of the object is subjected to an influence. In both cases the part of the object subjected to an influence changes its form in this or some other way and acquires a new form.

Speaking about the essence of the causativity in the space it is necessary to proceed from two types of the notion of space: a) subject space or causator space; b) object space or causate space. Toshovich notes that causal situation forms the basis of causativity. The participants of causativity (causator and causate), causative space 
and causative position form the casual situation. The main participants of causativity emerge in two forms: a) generator (source) of causativity or causator, b) object or causate subjected to instigation (Toshovich, 2000). Just these two participants of causativity (causator and causate) play an important role in the execution of causativity. In the concrete speech situation causator is instigator, but the causate being subjected to instigation functions as a unit, which changes its form in this or other way. Causator may be a human being, an animal and a phenomenon of nature. For example: The child broke the toy - Uşaq oyuncağl sindırdl. The wolf killed a sheep - Canavar bir qoyun öldürdü. The wind destroyed the house - Külak evi dağıtdl.

Sometimes causator may be explicit and implicit. It becomes obvious in the sentences of the type Somebody opened the door. In this sentence somebody as a causator is used explicitly. But in the sentence The door opened the causator functions implicitly. It is simply imagined that the door cannot open itself. Somebody or something has taken part in the opening of the door.

Speaking about the position of causativity in the space Toshovich notes that in causal constructions there may be one, two or several causates. For this purpose, he uses such terms as monocausator, bicausator, polycausator (Toshovich, 2000). Let us appeal to examples:

1) He bent his head - $O$, hörmat alamati olaraq başını aydi.

2) He closed his eyes - $O$, gözlarini yumdu.

3) They bent their heads - Onlar hörmət alaməti olaraq başlarını əydi.

In the first sentence we have a mono-causator, in the second one - a bicausator, in the third one - a polycausator. It is necessary to note that bicausator is used with the pair members of the human body: hands, eyes, feet, ears, brows - allar, gözlar, ayaqlar, qulaqlar, qaşlar etc. For example: He raised his hands. - $O$, allarini qaldırd.

\section{Conclusion}

Causate differs from causator in its position. Causator is subjected to changes under the influence of causator. Depending on the concrete speech situation causator has the following means of expression (Toshovich, 2000).

1) Causate is expressed by a human being: Mother washed the child. - Ana uşağl yudu.

2) Causate is expressed by an animal: The hunter killed the bear. - Ovçu ayını öldürdü.

3) Causate is expressed by a plant: The man cut the grass. - Kişi otu biçdi.

4) Causate is expressed by a lifeless thing: The soldier raised the flag. - Osgar bayră̆l qaldırdl.

We may make the following inferences by generalizing the above mentioned:

Causativity and causativity attracts the attention of the philosophers and linguists as a category of causation. The category of causation functions as a type of mutual interdependence. Though causativity and causativity differ from each other in essence, they form an interrelated binarity. Causality combines much broader meanings: initial condition, result determined in advance, result, stimule, purpose, etc. Causality finds its expression directly in different types of subordinate clauses. Causativity is a lexico-grammatical category, which reflects the relation of cause and consequence. Not depending of the means of expression causativity finds its expression in causative transitive verb. As a result of subject-object relation this or another thing is obliged to change its initial form, state, measure and others. Causativity emerges in simple and complicated forms. Simple causativity takes place as a result of a cause: The man forced the boy to follow him. In complicated causativity the subject acts both against the object and also instigates it to change its state: The boy broke the window. Causate and causator form the causal situation. Causator functions as an instigator, causate as something or someone subjected to instigation and is functioning as a unit changing its form. Causate and causator may be used with different parts of speech. The analysis of the language facts shows that causativity is inherent to the majority of languages as a universal category. Not only in separate languages, but even in a separately taken language causativity has different means of expression.

\section{References}

Abdullayev, A. A. (2011). Actual segmentation, text and discourse (pp. 20-120). Baku, Zardabi LTD LLC.

Arutyunova, N. D. (1976). Sentence and its meaning. Logical and semantic problems. Moscow, Publishing House Science.

Baklagova, U. V. (n.d.). To the question of causality and causation in the language system (pp. 3-10). Retrieved from https://cyberleninka.ru/article/n/k-voprosu-o-kauzalnosti-i-kauza-tivnosti-v-sisteme-yazyka

Bally, C. (1955). General linguistics and questions of the French language (pp. 110-130). Moscow, Publishing 
House of Foreign Literature.

Bunge, M. (1962). Causality, the place of the principle of causality in modern science. Translation from English. Publishing house of foreign literature. M.

Cheyf, W. L. (1975). The meaning and structure of language. Translation from English. M., Progress.

Katznelson, S. D. (1972). Typology of language and speech thinking. Leningrad. Publishing House Science. Leningrad branch.

Khanbutayeva, L. M. (2018). The role of syntactic units in speaking theory. Baku, Science and Education.

Reidel, A. I. (1971). The lexical and grammatical characteristic of causative verbs in a prepositional construct. Abstract. diss. ... cand. philol. sciences. M.

Tenier, L. (1988). Fundamentals of structural syntax. Translation from French. M., Progress.

Toshovich, B. (2000). Verbs of the causation of position in space. In Logical analysis of the language: Languages of spaces (pp. 157-170). M.

Turksever, O. I. et al. (2003). English-Azerbaijani Dictionary (pp. 21-25). Printing House, Gismet, Baki.

Typology of causative constructions. (1969). Morphological causative. Publishing House Science Leningrad Branch. L.

Veysalli, F. Y. (2015). Cognitive linguistics: main meanings and perspectives (pp. 20-74). Baku, Mutarim.

Yusifova, L. B. (2017). The expression of concept of compulsion in a language. Dissertation. Bak1.

Zolotova, G. A. (1973). Essay on the functional syntax of the Russian language. Moscow Publishing House Science.

\section{Copyrights}

Copyright for this article is retained by the author, with first publication rights granted to the journal.

This is an open-access article distributed under the terms and conditions of the Creative Commons Attribution license (http://creativecommons.org/licenses/by/4.0/). 